\title{
Towards exploration of plant-based ethno-medicinal knowledge of rural community: Basis for biodiversity conservation in Bangladesh
}

\author{
Mohammad Shaheed Hossain Chowdhury and Masao Koike*
}

Forest Policy Laboratory, Department of Forest Science, Faculty of Agriculture, Shinshu University, 8304 Minamiminowa-Mura, 399-4598 Nagano-Ken, Japan.

${ }^{*}$ Corresponding author:

E-mail: makoike@gipmc.shinshu-u.co.jp, shaheedfeni@yahoo.com

\begin{abstract}
Because lack of data impedes the assessment of the conservation of medicinal plants, ethno-medicinal studies are important to fill this gap. This study considered the traditional use of plants for health care by the rural communities in two forested and nonforested regions of Bangladesh. A total of 230 respondents were interviewed accompanied by field observation and voucher specimen collection. Altogether, 68 species of medicinal plants belonging to 38 families distributing over 58 genera were recorded, of which 22 species were common in both regions. Trees were the most commonly utilized growth form and leaves were the most commonly used plant part. Forests and homesteads were the major sources of medicinal plants in forested and nonforested regions, respectively. High use versatility (Relative Importance $>1$ ) was represented by 14 species; Emblica officinale L. and Allium sativum L. were the most versatile species. Forty-one individual ailments were treated with the medicinal plants recorded. The ailment categories 'respiratory problems' and 'sexual problems' received the highest score from the calculation of informants' consensus factor $\left(F_{i c}\right)$ in forested and non-forested regions, respectively. The findings could contribute in the pharmaceutical sector by directing further investigation of bio-active compounds in medicinal plants. Secondly, results could inform the clues for conservation strategies of forest resources in that region.
\end{abstract}

Key words: Medicinal plants, indigenous knowledge, informants' consensus factor, Bangladesh.

\section{Introduction}

Bangladesh has a total of 2.52 million ha forestland $(17.08 \%$ of the total land with actual vegetation coverage of $6.7 \%$ ), and forest area per 1000 people is only 6 ha (FAO 2010). About $74.5 \%$ of total populations live in rural areas (FAO 2010) and almost $80 \%$ of them are dependent on medicinal plants for primary health care (Chowdhury et al. 2009). Most of the rural people depend on medicinal plants growing in the homestead forests, also known as village forests (Halim et al. 2007), which cover about $13 \%$ of the total forestland area (Kibria et al. 2000). Out of the 64 districts of Bangladesh, 28 districts do 
not have any public natural forests; of the state-owned natural forests, over $90 \%$ is concentrated in 12 districts in the country's eastern and southwestern regions (Hossain 2008), mainly made up of hill forest and mangrove forest ecosystems. There are 20 protected areas in Bangladesh covering almost $2 \%$ of the country's total area and $11 \%$ of the total forestland area (BFD 2008). Most of the protected areas are located in the hilly regions and are in the interspersion of human habitation for a long period. People living in and around the conservation areas rely extensively on forest products to meet their everyday needs including primary health care (Mukul et al. 2007). Out of 5000 plant species of Bangladesh, 500 are claimed to have medicinal or curative properties (Ghani 2003).

The medicinal plant sector in Bangladesh is recognized as a priority domain of intervention by many stakeholders (Thomsen et al. 2005). The sector is worth US\$14 million with local supply comprised of $70 \%$ by volume and $40 \%$ by value (Dixie et al. 2003) with an estimate of around 12,000 tons of dried medicinal plants collected from rural and other naturally grown areas (Ahmed 2009). Ahmed also reported the existence of about 500 herbal industries in Bangladesh of which 20 are reasonably large and consume $80 \%$ of the total raw material demands. In conjunction with the increasing demand for traditional medicines in the country, research is being conducted on both the ethno-botanical documentation and pharmacological evaluation of the medicinal plants (e.g., Haque et al. 2000; Rahman et al. 2001; Lambertini et al. 2004; Uddin et al. 2006; Rahman et al. 2007; Mazumder and Rahman 2008; Rahman et al. 2008; Mollik et al. 2010).

The worldwide current trend towards unsustainable extraction of medicinal plants from natural habitats has resulted in over-harvesting, leading to threats to future productivity (Kala 2005). In contrast, careful exploitation of medicinal plants can provide an opportunity for local development (Purohit 1997). Guo et al. (1998) emphasized the exploration of traditional medicinal knowledge and experiences that may play a significant role in conserving local biodiversity. This is also necessary because such ethnographic research can provide important clues leading to new drugs for the modern pharmacies (Elujoba et al. 2005). Jain et al. (2010) reported the noteworthy contribution made by the traditional medicine to modern system where many drugs have been developed after analyzing the chemical constituents of plants traditionally used by the tribes and villagers. Therefore, taking all these dimensions of traditional medicine systems into consideration, the present study was conducted among local communities in two forested and non-forested regions of Bangladesh. Its aim was to assess the plantbased ethno-medicinal practice and document the traditional knowledge linked with it.

\section{Methodology \\ Study area}

The study was carried out in two different regions of Bangladesh: the northeastern hilly region and southeastern plains region which are the forested and non-forested regions respectively (Fig. 1). The former was represented by Rema-Kalenga Wildlife Sanctuary and the latter by the rural areas of Feni, a southeastern district devoid of natural forests. 


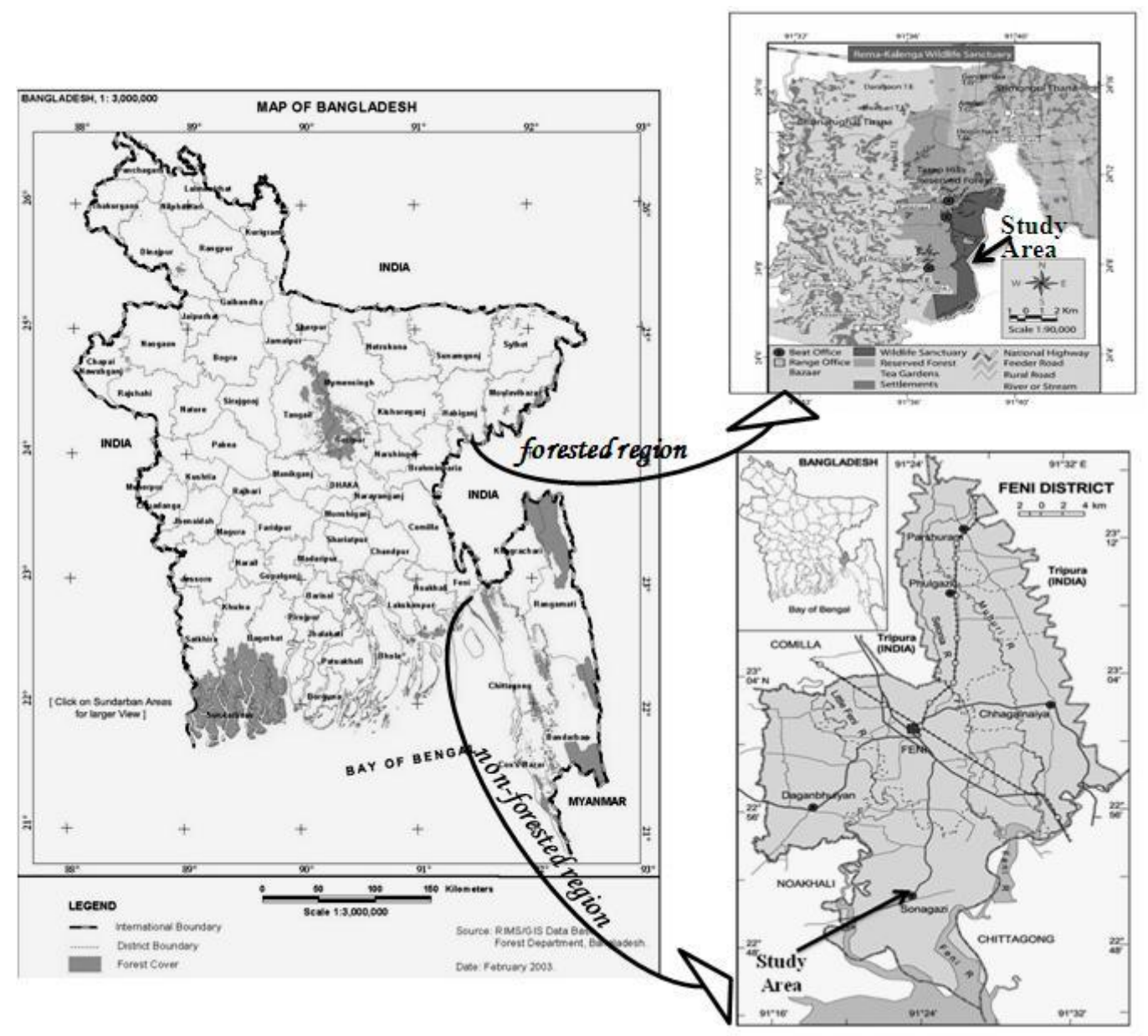

Figure 1. Location map of the study areas

Rema-Kalenga Wildlife Sanctuary (RKWS) lies between $24^{\circ} 06^{\prime}-24^{\circ} 14^{\prime} \mathrm{N}$ latitude and $91^{\circ} 34^{\prime}-91^{\circ} 41^{\prime} \mathrm{E}$ longitude (BCAS 1997). The vegetation of the sanctuary is characterized as tropical evergreen and semi-evergreen forest, with an estimated total of 606 plant species (242 herbs, 120 shrubs, 147 trees and 97 climbers) (Uddin 2001). A total of 36 villages having varying degrees of stake with the sanctuary have been identified; one located inside, nine at the boundary and 26 are outside. Agriculture is the primary occupation of the people living both inside and outside the sanctuary.

Feni district is a transitional zone between the southeastern vast hilly regions (Chittagong Hill Tracts) and other plains regions in the southern and middle of the country lying between $23^{\circ} 01 ' \mathrm{~N}$ latitude and $91^{\circ} 24^{\prime} \mathrm{E}$ longitude (Tageo 2010). The district supports a population of $1,196,219$ with a literacy rate of $40.7 \%$. Most people (36.67\%) have agriculture as their major occupation. Feni is one of those 28 districts where literally no natural forests are located, rather marginal lands have become forested with the plantations of both indigenous and exotic tree species, where herbs and shrubs grow deliberately as understory (Chowdhury et al. 2009). 


\section{Data collection}

The study was conducted from the middle of 2007 to the earliest of 2009, using a multistage random sampling method. In case of the forested region, RKWS was selected purposively because of its rich biodiversity. A total of 140 inhabitants living in the villages inside and at the boundary of the sanctuary were selected randomly for the study. In the case of non-forested region, Sonagazi was chosen from the six upazillas of Feni district because it is the southernmost region facing the Bay of Bengal and bordered by two rivers- the Feni and Choto Feni- to the east and west. Due to its geographical location, the upazilla is more or less flooded during the rainy season, resulting in deposition of sediments that increases the productivity of land, ultimately contributing to its botanical diversity. From the upazilla, three villages were selected at random; from each of the three villages, 30 households (irrespective of socio-economic condition) were selected randomly for the comprehensive study totaling 90 households. Thus a total of 230 households were selected from the two regions.

The method used to gather information was the qualitative approach of ethno-botanical interview. The interviewing team was composed of four members headed by the first author; voluntarily assisted by the other three who were post graduate students of the Department of Forestry and Environmental Science in the Shahjalal University of Science and Technology. At the family level, informal meetings were held in the interviewee's home using the native language (Bangla), sometimes with the participation of more than one randomly selected respondent together. In addition, six focus group discussions, three in each region, were arranged in the tea stalls of local market where the rural people usually get together, gossip and interact in the evening after the day-long business. All the data was collected from repeated conversations with the respondents living close to plants, to ensure the reliability of the information. This model is what anthropologists know as a semi-structured, focalized interview (Parada et al. 2009). The household heads were the key respondents, with help from other family members when necessary.

The main purpose was to obtain the information about medicinal plants used and/or known by the respondents and document the knowledge on their application. The plants used for medicinal purposes were first recorded using local names and conventional Bangla names. Although local names of plants vary from region to region within the country, established Bangla names have been well documented by Dey (2006) together with the various local names. Once local names had been obtained, the corresponding Bangla names were found by reference to Dey (2006). Voucher specimens of each medicinal plant species were also collected during the field visit and allotted collection numbers. The collected specimens were then dried and identified using standard literatures (e.g., Chevallier 1996; Das and Alam 2001; Dey 2006) along with the help of a professional taxonomist of Bangladesh Forest Research Institute (BFRI). Vouchers in the form of herbarium were deposited in the laboratory of the Department of Forestry and Environmental Science in Shahjalal University of Science and Technology, Bangladesh. 


\section{Data Analysis}

Apart from the qualitative enlistment of the species (with scientific and Bangla names, family and habit), their parts used, and ailments treated; we calculated the relative importance $(\mathrm{RI})$ for each species and informant consensus factor $\left(\mathrm{F}_{\mathrm{ic}}\right)$ for each ailment category.

The relative importance (RI) of the species was calculated adopting Bennett and Prance (2000) according to the following formula, with " 2 ", being the highest possible value, indicating the most versatile species (those species that have the greatest number of medicinal properties):

$\mathrm{RI}=\mathrm{NCS}+\mathrm{NP}$

Where NCS is obtained by dividing the number of ailment category treated with a given species by the total number of ailment categories treated with the most versatile species and NP is obtained by dividing the number of individual ailments attributed to a given species by the total number of individual ailments attributed to the most versatile species.

The informant consensus factor $\left(\mathrm{F}_{\mathrm{ic}}\right)$ was employed to indicate the homogeneity of the information. All citations were placed into ailment categories for which the species was claimed to be used. The $F_{\text {ic }}$ value ranges from 0 to 1 . A high value (close to 1 ) indicates that the species is relatively used by a large proportion of the informants indicating a more consistent use of the medical resources. On the other hand, a low value indicates that informants disagree on the species to be used in treatment within a category of ailment. In other words, the $F_{\text {ic }}$ is an indicative value of how much the informants are consistent and the extent they agree about the use of certain plant species for treatment of a given ailment or ailment category (Hudaib et al. 2008).

The $F_{\text {ic }}$ was calculated sensu Trotter and Logan (1986) according to the following formula:

$\mathrm{F}_{\mathrm{ic}}=\mathrm{N}_{\mathrm{ur}}-\mathrm{N}_{\mathrm{t}} / \mathrm{N}_{\mathrm{ur}}-1$

Where $\mathrm{N}_{\mathrm{ur}}$ is the number of use citations in each ailment category and $\mathrm{N}_{\mathrm{t}}$ is the number of species used.

\section{Results and discussion}

\section{Medicinal plants recorded}

The local communities in both the forested and non-forested regions were found to use plants for health care purposes. Altogether a total of 68 plant species belonging to 38 families distributed over 58 genera were recorded from the study areas. Twenty-two species $(32.35 \%$ of the total), 21 families $(55.26 \%$ of the total) and 21 genera $(36.21 \%$ of the total) were found common in both regions (Table 1). Among the medicinal plants, trees were the most frequent growth form (33.82\%) followed by shrubs $(26.47 \%)$, herbs $(25 \%)$, creepers $(11.70 \%)$ and palms $(2.94 \%)$. In general, trees are the mostly used growth form of medicinal plants in rural Bangladesh as depicted in several studies (e.g., 
Miah and Chowdhury 2003; Mukul et al. 2007; Chowdhury et al. 2009) with a few exceptions as in Halim et al. (2007) where they found that trees were used least among a religio-cultural group in southwestern part of the country. Other than Bangladesh, trees were found dominant medicinal plants among the Tharus, a forest dweller community of Nepal (Ghimire and Bastakoti 2009) unlike in Ethiopia where it was dominated by herbs (Dawit and Estifanos 1991; Yineger et al. 2008).

Table 1. Frequency of number and growth form of medicinal plants reported in the study areas

\begin{tabular}{|l|l|l|l|l|l|l|l|l|}
\hline Regional & Total & No. & No. & \multicolumn{3}{|l|}{ Habit (\% of total plants reported) } \\
identity & $\begin{array}{l}\text { plants } \\
\text { reported }\end{array}$ & $\begin{array}{l}\text { of } \\
\text { family }\end{array}$ & $\begin{array}{l}\text { of } \\
\text { genus }\end{array}$ & Herb & Shrub & Tree & Creeper & Palm \\
\hline Forested & 44 & 28 & 36 & 23 & 32 & 34 & 11 & - \\
\hline Non-forested & 46 & 31 & 40 & 26 & 26 & 35 & 9 & 4 \\
\hline $\begin{array}{l}\text { Common in } \\
\text { both regions }\end{array}$ & 22 & 21 & 21 & 8.82 & 7.69 & 13.24 & 1.47 & - \\
\hline
\end{tabular}

Of the 38 families recorded with medicinal properties, six represented highest number of species such as Combretaceae, Compositae, Euphorbiaceae, Fabaceae, Liliaceae and Rutaceae, each having three species. Among the rests, 12 families were represented by two species each and the others had one species per family. The wide therapeutic use of some botanical families, recorded in the study areas, was also reported in other communities throughout the world. These are Apocynaceae and Asclepiadaceae among the Jaintia in India (Sajem and Gosai 2006); Fabaceae, Moraceae, Cucurbitaceae, Apocynaceae and Euphorbiaceae among the Tharus in Nepal (Ghimire and Bastakoti 2009); and Umbelliferae among the Tibetans of Yunnan Province in China (Liu et al, 2009). The list of medicinal plants recorded, their habits, families, parts used, ailments treated and relative importance are given in Appendix-A.

\section{Source of medicinal plants}

The communities of the forested region collected medicinal plants mainly from the forests around RKWS (72.72\%). Homesteads and market served as the supplementary sources in equal proportion, $13.64 \%$ each. On the other hand, communities of nonforested region used their homesteads as the vital source (32.61\%) of medicinal plants followed by anthropogenic environments $(28.26 \%)$, markets $(26.09 \%)$, homestead-andmarket $(8.69 \%)$ and cultivated habitat $(4.35 \%)$. A variation in the source of medicinal plants was noticed in two different regions. Generally, homesteads (homegardens) are the traditional agroforestry practices in rural Bangladesh where a number of crops including trees are grown with livestock, poultry and fish mainly to satisfy the farmers' basic needs. These are primarily used to grow plants for household consumption, consequently food 
and fruit species predominate there along with the species supplying timber, fuel wood, fodder and medicine. Since the communities in and around RKWS live in the vicinity of forest within easy reach of medicinal plants, they were found to be less concerned about the homegarden biodiversity. Conversely, due to the absence of natural forests around, the communities in Feni district were found to search for alternative sources other than homegardens, because a considerable portion of the landscape was covered by the anthropogenic environments. These comprise diverse habitats such as graveyards, jungles, fallow lands, hinterlands, roadsides, pond and canal banks and traditional village groves. The communities collect mainly herbaceous plants from these habitats because growth forms other than herbs are abundant in their homesteads. Stepp and Moerman (2001) and Gazzaneo et al. (2005) found the similar trend of collecting medicinal plants from anthropogenic habitats by the Maya communities of Mexico and the local herbal specialists of northeastern Brazil, respectively.

Forests are found as the fundamental source of medicinal plants in many other communities throughout the world. For instances, forest species formed $82.3 \%$ of the total medicinal plants collected by the Baka Pygmy community in Dja Biosphere Reserve in Cameroon (Betti 2004); more than $90 \%$ by the Shaiji group of southwestern Bangladesh (Halim et al. 2007); 85.71\% by the local healers in Sekoru district of southwestern Ethiopia (Yineger and Yewhalaw 2007); 83.64\% by the local community in Bale Mountains National Park of southeastern Ethiopia (Yineger et al. 2008); and 80.10\% by the local people in Yunnan Province of southwestern China (Lee et al. 2008). Uniyal et al. (2000) revealed that medicinal properties of plant secondary metabolites are produced more in wild species grown under stress and competition and are not always expressed in fast-growing monoculture. Moreover, plants grow more slowly in wild populations and may have higher levels of active compounds. However, some species with multiple uses, either as vegetables or spices and condiments, were found cultivated in the non-forested region of our study areas. Momordica charantia L. and Zingiber officinale Rosc. are two such species.

\section{Plant parts utilization}

For curing ailments, use of both the above- and below-ground plant parts was reported in the study areas. The use of above-ground plant parts was higher in both the regions than the below-ground parts- constituting about $80 \%$ of the total species recorded. Varieties of plant parts utilized included the leaf, fruit, bark, root and others. Leaves were found to be the mostly used part in both the regions (Fig. 2). The category 'others' includes flower, seed, inflorescence, stem, twig, petiole, latex, bulb, tuber and whole plant. The ample use of leaves was due to its continuous temporal availability which has also been reported in many other communities (e.g., Giday 2001; Sajem and Gosai 2006; Yineger and Yewhalaw 2007; Langenberger et al. 2009; Rana et al. 2009). The plentiful use of leaves can ensure sustainable harvesting of medicinal plants (Halim et al. 2007) that provides an incentive to protect and maintain wild populations, their habitats and the genetic diversity (Schippmann et al. 2002). However, variations on the use of medicinal plant parts are also reported in the literature. For instances, roots were mostly used in southeastern Ethiopia (Lulekal et al. 2008), Yunnan Province of China (Liu et al. 2009), and Nawalparasi district of central Nepal (Ghimire and Bastakoti 2009); flowers in 
northeastern Brazil (Almeida et al. 2006) and Manang district of central Nepal (Bhattarai et al. 2006); and twigs in Suriname (Andel and Havinga 2008).

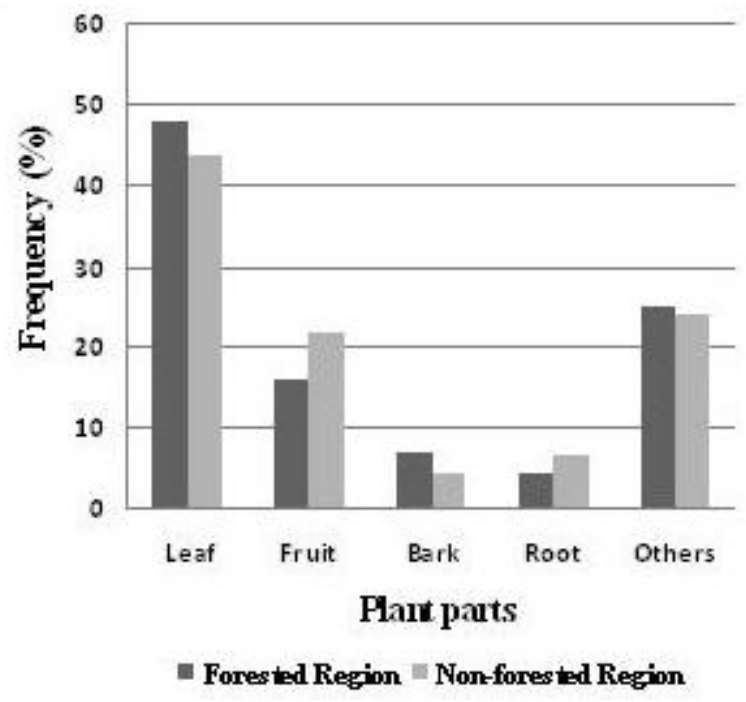

Figure 2. Various plant parts used in the study areas

Altogether 41 ailments were reported in the two regions among which, 18 (43.90\%) were reported common in both the regions. When expressed region-wise, 33 ailments $(80.49 \%$ of the grand total) were reported by interviewees in the forested area and $26(63.41 \%)$ from the non-forested one. All ailments were treated with the medicinal plants recorded in the study areas. In some cases, different parts of an individual plant were used for treating different ailments; in other cases, different parts of more than one plant were mixed together and applied to treat a single ailment. Most plant parts were consumed orally after processing such as macerating, pounding, squeezing, blending, soaking or boiling in water, rubbing or burning. Some were taken raw and some after cooking as vegetables. Some were applied externally to different body parts, especially for treating cuts and wounds, scabies, pain or skin diseases.

\section{Relative Importance (RI) of species and Informants' Consensus Factor $\left(F_{\text {ic }}\right)$ on medicinal knowledge}

In the forested region, five species were found with high use versatility (RI $>1)$ : Clerodendrum viscosum Vent. (1.10), Trewia nudiflora L. (1.10), Terminalia chebula Retz. (1.55), Terminalia belerica Roxb. (1.88) and Emblica officinale L. (2.00). These constituted about $11 \%$ of the total medicinal species recorded there. On the other hand, nine such species were reported in the non-forested region: Aloe indica Tow. (1.10), Aegle marmelos (L.) Correa. (1.30), Mikania scandens (L.) Willd. (1.35), Swertia chirata Ham. (1.55), Plantago ovate Forst. (1.55), Cocos nucifera L. (1.55), Azadirachta indica Juss. (1.55), Piper betel L. (1.55) and Allium sativum L. (2.00). These constituted about $20 \%$ of the total medicinal species recorded there. It is quite interesting that species with high use versatility are located more in the non-forested region than in the forested region. Five species out of those nine were not endemic to that area and bought from the 
vendors in local market who collect them from outside the region. On the contrary, all of the five highly versatile species are indigenous to the forested region, and the community generally likes to use the species available in the surrounding forests rather than buying from market.

Table 2. Various ailment categories treated with medicinal plants in the study areas

\begin{tabular}{|c|c|c|}
\hline Ailment category & Biomedical term & Region of availability \\
\hline \multirow[t]{4}{*}{ Dermatological } & Cuts \& wounds & Both \\
\hline & Scabies & Both \\
\hline & Skin diseases & Both \\
\hline & Dandruff & Non-forested only \\
\hline \multirow[t]{8}{*}{ Gastrointestinal } & Diarrhea & Both \\
\hline & Dysentery & Both \\
\hline & Flatulence & Both \\
\hline & Gastric pain & Both \\
\hline & Intestinal worm & Both \\
\hline & Stomach trouble & Both \\
\hline & Vomiting & Non-forested only \\
\hline & Liver disease & Non-forested only \\
\hline \multirow[t]{8}{*}{ General health } & Apathy to food intake & Both \\
\hline & Cold & Both \\
\hline & Chronic fever & Forested only \\
\hline & Fever & Both \\
\hline & Heart disease & Both \\
\hline & Leg swelling & Forested only \\
\hline & Stammering & Forested only \\
\hline & Weakness & Forested only \\
\hline
\end{tabular}




\begin{tabular}{|c|c|c|}
\hline & Heat stroke & Non-forested only \\
\hline & Faintness & Non-forested only \\
\hline & Oral disorders & Non-forested only \\
\hline Faunal bites & Leech bite & Forested only \\
\hline & Mosquito bite & Forested only \\
\hline & Snake bite & Forested only \\
\hline Jaundice & & Forested only \\
\hline Malaria & & Forested only \\
\hline Pain & Rheumatism & Both \\
\hline & Head ache & Forested only \\
\hline & Earache & Non-forested only \\
\hline Respiratory & Asthma & Forested only \\
\hline & Cough & Both \\
\hline & Tonsil pain & Non-forested only \\
\hline Sexual & Birth control & Forested only \\
\hline & Female disease & Forested only \\
\hline & Low sperm content in male & Forested only \\
\hline & Premature ejaculation in male & Forested only \\
\hline & Sexual weakness in male & Both \\
\hline Urinary & Burning in urination & Both \\
\hline & Diabetes & Both \\
\hline
\end{tabular}

All of the 41 ailments were grouped into predefined ethno-botany categories (Heinrich 2000), with the addition of a few others, forming 10 broad ailment categories altogether (Table 2) The $F_{\text {ic }}$ values were assessed for the categorized ailments (Table 3 ) that indicate the degree of shared knowledge among the respondents for the treatment of the ailments by medicinal plants. The greater the consensus factor the more likely it is that the remedy 
has bioactive molecules (Owuor and Kisangau 2006). Three ailment categories like faunal bites, jaundice and malaria were found only in the forested region and the remaining seven categories were found in both regions in various proportions. For instance, in some cases, all the individual ailments under one category were found in both regions and in some cases, only one or two from a category were found in one region and the remaining in another region. Among the 10 ailment categories in our study, respiratory problems $(0.56)$ and sexual problems (1.00) scored the highest $F_{\text {ic }}$ values in forested region and non-forested region, respectively. Thirteen species, representing about $30 \%$ of the total species recorded in forested region were used for the treatment of respiratory problems that included asthma and cough. On the other hand, only one species $(2.17 \%$ of the total species recorded) was used for sexual problems that included a single ailment-sexual weakness in males- in the non-forested region. No consensus $\left(F_{i c}=0\right)$ was found among the informants of the forested region for the categories malaria and pain, while no such ailment category with zero $F_{\text {ic }}$ value was found in the nonforested region. This suggests the uniformity and rigidity in traditional ethno-medicinal knowledge is higher in the communities of the non-forested region. This may be because of their long time acquaintances with the region, whereas most of the communities of forested region have more recently migrated from other regions and settled in the public lands in and around RKWS. $F_{\text {ic }}$ is an important tool for measuring the degree of shared knowledge among local communities and has been used by several other ethno-botanists (e.g., Heinrich 2000; Camejo-Rodrigues 2003; Owuor and Kisangau 2006; Ragupathy et al. 2007; Hudaib et al. 2008; Al-Qura'n 2009).

Table 3. Degree of local communities' consensus on managing various ailments with medicinal plants

\begin{tabular}{|c|c|c|c|c|c|c|c|c|}
\hline \multirow{2}{*}{$\begin{array}{l}\text { Ailment } \\
\text { category/ } \\
\text { Regional } \\
\text { identity }\end{array}$} & \multicolumn{2}{|c|}{$\begin{array}{l}\text { No. of plants } \\
\text { species }\end{array}$} & \multicolumn{2}{|c|}{$\begin{array}{l}\text { Percentage of } \\
\text { total species* }\end{array}$} & \multicolumn{2}{|c|}{$\begin{array}{l}\text { No. of use- } \\
\text { reports }\end{array}$} & \multicolumn{2}{|l|}{$F_{i c}$} \\
\hline & Forested & $\begin{array}{l}\text { Non- } \\
\text { foreste } \\
\text { d }\end{array}$ & $\begin{array}{l}\text { Foreste } \\
\text { d }\end{array}$ & $\begin{array}{l}\text { Non- } \\
\text { foreste } \\
d\end{array}$ & $\begin{array}{l}\text { Foreste } \\
\text { d }\end{array}$ & $\begin{array}{l}\text { Non- } \\
\text { foreste } \\
\text { d }\end{array}$ & $\begin{array}{l}\text { Foreste } \\
\text { d }\end{array}$ & $\begin{array}{l}\text { Non- } \\
\text { foreste } \\
\text { d }\end{array}$ \\
\hline $\begin{array}{l}\text { Dermato- } \\
\text { logical }\end{array}$ & 7 & 11 & 15.91 & 23.91 & 9 & 14 & 0.25 & 0.23 \\
\hline $\begin{array}{l}\text { Gastro- } \\
\text { intestinal }\end{array}$ & 17 & 18 & 38.64 & 39.13 & 29 & 33 & 0.43 & 0.47 \\
\hline $\begin{array}{l}\text { General } \\
\text { health }\end{array}$ & 13 & 18 & 29.55 & 39.13 & 20 & 47 & 0.37 & 0.63 \\
\hline Faunal bite & 3 & - & 6.82 & - & 4 & - & 0.33 & - \\
\hline
\end{tabular}




\begin{tabular}{|l|l|l|l|l|l|l|l|l|}
\hline Jaundice & 5 & - & 11.36 & - & 10 & - & 0.55 & - \\
\hline Malaria & 3 & - & 6.82 & - & 3 & - & 0.00 & - \\
\hline Pain & 2 & 3 & 4.55 & 6.52 & 2 & 5 & 0.00 & 0.50 \\
\hline Respiratory & 13 & 5 & 29.55 & 10.87 & 28 & 7 & 0.56 & 0.33 \\
\hline Sexual & 5 & 1 & 11.36 & 2.17 & 6 & 3 & 0.20 & 1.00 \\
\hline Urinary & 3 & 10 & 6.82 & 21.74 & 5 & 16 & 0.50 & 0.40 \\
\hline
\end{tabular}

*Percentage sum exceeds 100 as some species are in use against more than one category.

\section{Myths and traditional beliefs regarding medicinal plants}

During the study, a number of myths and traditional beliefs were explored, most of which were common in both the regions. Some people possess keenness to raise certain species having medicinal properties, particularly Azadirachta indica Juss., Punica granatum L., Lawsonia inermis L., Ocimum sanctum L. and Areca catechu L. in their homesteads. Azadirachta indica Juss. is usually planted on the southern side of the homestead in the belief that air from the south is purified by its foliage. People took special care of this plant in terms of watering, supporting with sticks, and removing dried leaves and branches in the early stage. Lawsonia inermis L. and Ocimum sanctum L. are viewed as sacred plants by the Muslim and Hindu religious communities, respectively and are the most cared-for species in the study areas. The leaf of Lawsonia inermis L. is often used in dyeing the hand palms of women and children on religious occasions, and of bridal couples, and is more generally in the Muslim community. The younger family members sometimes put their own blood at the base of this plant at the time of planting, hoping for its long life. In the Hindu community, the leaf of Ocimum sanctum L. is used commonly in worship; the earth around the base of this species is kept neat and clean, with regular mud paste added by older women. Miah and Rahman (2006) also reported on these two plants and their religious significance having positive effects on the floral stock of the Muslim and Hindu homesteads in Bangladesh; while Chowdhury et al. (2010) reported the livelihood potential of the commercial farming of Lawsonia inermis L. in the central part of the country. Some species (e.g., Aloe indica Tow., Kalanchoe pinnata (Lamk.) Pers. and Tagetes erecta L.) are grown in earthen pots in the study areas and kept in front of dwelling houses, serving both beautification and medicinal purposes. Tamarindus indica (L.) Cogn. is planted either in the periphery of homesteads or in fallow lands of the back yard with a belief that evil spirits take shelter on its crown.

\section{Conclusion}

The rural communities of Bangladesh, irrespective of forested and non-forested regions, are dependent on medicinal plants for primary health care purposes. Although the choice, pattern and mode of using medicinal plants by the communities in two different regions vary to some extent; their knowledge is similar in many cases, e.g., usage of leaves in 
higher proportions, preference for species grown wild, giving special care to certain species in homesteads, etc. These may give an important basis for guiding the conservation strategy for the regional plants since medicinal plants started disappearing rapidly due to their commercialization, increased demand and unsustainable harvesting (Rai et al. 2000). Moreover, traditional knowledge of the local communities in the study areas may provide the scientific communities with the clues for screening plants as a potential source for bioactive compounds that could result in discovery of novel antimicrobial agents. Already in many countries, scientific investigations of medicinal plants have been initiated because of their potential (Patrick 2002). The government may follow this thinking by launching programs in collaboration with Bangladesh Forest Research Institute (BFRI) and Bangladesh Council for Scientific and Industrial Research (BCSIR). This study can inform both local and global knowledge of the importance of medicinal plants and its conservation.

\section{Acknowledgement}

The authors sincerely extend their thanks to Laura Applegate, Washington State University for her voluntary assistance in editing language of the manuscript. They also thank Shampa Biswas, School of Environmental Sciences and Management, Independent University of Bangladesh for establishing communication with Laura Applegate in this regard. The authors are grateful to the respondents for their all-out cooperation during field work. They acknowledge the Ministry of Science and Education, Japan for granting scholarship to support the research and study of the first author. Finally, thanks are extended to the editor and anonymous reviewers for their valuable comments on earlier drafts of this manuscript.

\section{References}

Almeida CFCBR, Amorim ELC, Albuquerque UP, Maia MBS (2006) Medicinal plants popularly used in Xingo region- a semi-arid location in Northeastern Brazil. J Ethnobiol Ethnomed 2: 1-15.

Al-Qura'n S (2009) Ethnopharmacological survey of wild medicinal plants in Showbak, Jordan. J Ethnopharmacol 123: 45-50.

Andel TV, Havinga R (2008) Sustainability aspects of commercial medicinal plant harvesting in Suriname. For Ecol Manag 256: 1540-1545.

BCAS (1997) Biological survey. Final report, Prepared for Forest Resources Management Project of Forest Department, Bangladesh Center for Advanced Studies, Dhaka.

Bennett BC, Prance GT (2000) Introduced plants in the indigenous pharmacopoeia of Northern South America. Econ Bot 54: 90-102.

Betti JL (2004) An ethnobotanical study of medicinal plants among the Baka Pygmies in the Dja Biosphere Reserve, Cameroon. Afr Stud Monogr 25: 1-27. 
BFD (2008) Bangladesh Forest Department. Ministry of Environment and Forest, Government of Bangladesh, Dhaka.

Bhattarai S, Chaudhary RP, Taylor RSL (2006) Ethnomedicinal plants used by the people of Manang district, central Nepal. J Ethnobiol Ethnomed 2: 1-8.

Camejo-Rodrigues J, Ascensao L, Bonet MA, Valles J (2003) An ethnobotanical study of medicinal and aromatic plants in the Natural Park of "Serra de Sao Mamede" (Portugal). J Ethnopharmacol 89: 199-209.

Chevallier A (1996) The encyclopedia of medicinal plants. $1^{\text {st }}$ edition. DK Publishing Inc. New York, USA.

Chowdhury MSH, Koike M, Muhammed N, Halim MA, Saha N, Kobayashi H (2009) Use of plants in healthcare: A traditional ethno-medicinal practice in rural areas of southeastern Bangladesh. Int J Biodiv Sci Manag 5: 41-51.

Chowdhury MSH, Rahman MM, Koike M, Muhammed N, Salahuddin KM, Halim MA, Saha N, Rana MP, Islam MJ (2010) Small-scale mehedi (Lawsonia inermis L.) farming in the central Bangladesh: A promising NTFP-based rural livelihood outside the forests. Small-scale For 9: 93-105.

Das KD, Alam MK (2001) Trees of Bangladesh. Bangladesh Forest Research Institute (BFRI), Chittagong, Bangladesh.

Dawit A, Estifanos H (1991) Plants as a primary source of drugs in the traditional health practices of Ethiopia. In: Engles JMM, Hawkes JG, Worede M (eds) Plant genetic resources of Ethiopia. Cambridge University Press, Cambridge, UK, pp. 101-113.

Dey TK (2006) Useful plants of Bangladesh. $2^{\text {nd }}$ edition. The Ad. Communication, Chittagond, Bangladesh.

Elujoba AA, Odeleye OM, Ogunyemi CM (2005) Traditional medicine development for medical and dental primary health care delivery system in Africa. Afr J Trad, Comp Alt Med 2: 46-61.

FAO (2010) State of the world's forests 2009. FAO Corporate Document Repository. Food and Agriculture Organization. http://www.fao.org/docrep/011/i0350000.HTM Accessed 16 January 2010.

Gazzaneo LRS, de Lucena RFP, de Albuquerque (2005) Knowledge and use of medicinal plants by local specialists in a region of Atlantic forest in the state of Pernambuco (Northeastern Brazil). J Ethnobiol Ethnomed 1(9). DOI: 10.1186/1746-4269-1-9.

Ghani A (2003) Medicinal plants of Bangladesh with chemical constituents and uses. Asiatic Society of Bangladesh, Ramna, Dhaka, Bangladesh.

Ghimire K, Bastakoti RR (2009) Ethnomedicinal knowledge and healthcare practices among the Tharus of Nawalparasi district in central Nepal. For Ecol Manag 257: 2066-2072. 
Giday M (2001) An ethnobotanical study of medicinal plants used by the Zay people in Ethiopia. CBM:s Skriftserie 3: 81-99.

Guo HJ, Long CL (1998) Biodiversity of Yunnan Kunming. Yunnan Science and Technology Press, China.

Halim MA, Chowdhury MSH, Wadud AI, Uddin MS, Sarker SK, Uddin MB (2007) The use of plants in traditional health care practice of the Shaiji community in southwestern Bangladesh. J Trop For Sci 19:168-175.

Haque N, Chowdhury SAR, Nutan MTH, Rahman GMS, Rahman KM, Rashid MA (2000) Evaluation of antitumor activity of some medicinal plants of Bangladesh by potato disc bioassay. Fitoterapia 71: 547-552.

Heinrich M (2000) Ethnobotany and its role in drug development. Phytother Res 14: 479488.

Hossain S (2008) Participatory forest management in Bangladesh. www.iges.or.jp/en/fc/phase1/2ws-3-Bangla.pdf. Accessed 19 September 2008.

Hudaib M, Mohammad M, Bustanji Y, Tayyem R, Yousef M, Abuirjeie M, Aburjai T (2008) Ethnopharmacological survey of medicinal plants in Jordan, Mujib Nature Reserve and surrounding area. J Ethnopharmacol 120: 63-71.

Jain DL, Baheti AM, Jain SR, Khandelwal KR (2010) Use of medicinal plants among tribes in Satpuda region of Dhule and Jalgaon districts of Maharashtra- An ethnobotanical survey. Indian J Trad Knowl 9(1): 152-157.

Kala CP (2005) Indigenous uses, population density, and conservation of threatened medicinal plants in protected areas of the Indian Himalayas. Conserv Biol 19: 368-378.

Kibria MG, Sarker DC, Hossain MA, Mannan MA, Motaleb MA, Islam SS (2000) Forest statistics of Bangladesh. Bulletin 4. Forest Economics Division, BFRI, Chittagong, Bangladesh.

Lambertini E, Piva R, Mahmud THK, Lampronti I, Bianchi N, Borgatti M, Gambari R (2004) Effects of extracts from Bangladeshi medicinal plants on in vitro proliferation human breast cancer cell lines and expression of estrogen receptor. Int J Oncol 24: 419-423.

Langenberger G, Prigge V, Martin K, Belonias B, Sauerborn J (2009) Ethnobotanical knowledge of Philippine lowland farmers and its application in agroforestry. Agrofor Sys 76: 173-194.

Lee S, Xiao C, Pei S (2008) Ethnobotanical survey of medicinal plants at periodic markets of Honghe Prefecture in Yunnan Province, SW China. J Ethnopharmacol117: 362-377. 
Liu Y, Dao Z, Yang C, Liu Y, Long C (2009) Medicinal plants used by Tibetans in Shangri-la, Yunnan, China. J Ethnobiol Ethnomed 5: 1-10. Doi: 10.1186/17464269-5-15.

Lulekal E, Kelbessa E, Bekele T, Yineger H (2008) An ethnobotanical study of medicinal plants in Mana Angetu District, southeastern Ethiopia. J Ethnobiol Ethnomed 10: Doi: 10.1186/1746-4269-4-10.

Mazumder MEH, Rahman S (2008) Pharmacological evaluation of Bangladeshi medicinal plants for antioxidant activity. Pharmaceu Biol 46: 704-709.

Miah MD, Chowdhury MSH (2003) Indigenous healthcare practice through medicinal plants from forests by the Mro tribe in Bandarban region, Bangladesh. Indilinga: Afr J Indigen Knowl Sys 2:61-73.

Miah MD, Rahman MM (2006) The effect of religious sub-culture on the stock and diversity of the village forests in the floodplain area of Bangladesh. For, Trees Live 16: 139-150.

Mollik MAH, McField R, Faruque MR, Thapa KM, Hassan AI, Ahmmed B (2010) Ethnomedicinal uses of some medicinal plants for prevention against all forms of cancer by the traditional healers in Gazipur district of Bangladesh. Canc Prev Res 3(1 Suppl): A101.

Mukul SA, Uddin MB, Tito MR (2007) Medicinal plant diversity and local healthcare among the people living in and around a conservation area of northern Bangladesh. Int J For Usufr Manag 8: 50-63.

Owuor BO, Kisangau DP (2006) Kenyan medicinal plants used as antivenin: A comparison of plant usage. J Ethnobiol Ethnomed 2: 1-7.

Parada M, Carrio E, Bonet MA, Valles J (2009) Ethnobotany of the Alt Emporda region (Catalonia, Iberian Peninsula): Plants used in human traditional medicine. J Ethnopharmacol. Doi: 10.1016/j.jep.2009.04.050.

Patrick OE (2002) Herbal medicines: Challenges. Trop J Pharmacol Res 1: 53-54.

Purohit AN (1997) Medicinal plants- Upgrading technology for trading the traditions. In: Proceedings in National Seminar on Harvesting Herbs 2000. HAPPRC Srinagar Garhwal.

Ragupathy S, Steven NG, Maruthakkutti M, Velusamy B, Ul-Huda MM (2007) Consensus of the 'Malasars' traditional aboriginal knowledge of medicinal plants in the Vellangiri holy hills, India. J Ethnobiol Ethnomed 4: 1-8.

Rahman S, Hasnat A, Hasan CM, Rashid MA, Ilias M (2001) Pharmacological evaluation of Bangladeshi medicinal plants- A review. Pharmaceu Biol 39: 1-6. 
Rahman MA, Uddin SB, Wilcock CC (2007) Medicinal plants used by Chakma tribes in Hill Tracts districts of Bangladesh. Indian J Trad Knowl 6: 508-517.

Rahman MS, Begum B, Chowdhury R, Rahman KM, Rashid MA (2008) Preliminary cytotoxicity screening of some medicinal plants of Bangladesh. Dhaka Univ J Pharmaceu Sci 7: 47-52.

Rai LK, Prasad P, Sharma E (2000) Conservation threats to some important medicinal plants of the Sikkim Himalaya. Biol Conserv 93: 27-33.

Rana MP, Sohel MSI, Akhter S, Hassan MR (2009) The use of plants in indigenous health care practice of the Hajong tribe community in northeastern Bangladesh. $\mathrm{J}$ For Sci 25: 25-33.

Sajem AL, Gosai K (2006) Traditional use of medicinal plants by the Jaintia tribes in North Cachar Hills district of Assam, northeast India. J Ethnobiol Ethnomed 2(33). Doi: 10.1186/1746-4269-2-33.

Schippmann U, Leaman DJ, Cunningham AB (2002) Impact of cultivation and gathering of medicinal plants on biodiversity: Global trends and issues. In: Biodiversity and ecosystem approach in agriculture, forestry and fisheries. Satellite event in Ninth Regular Session of the Commission on Genetic Resources for Food and Agriculture, 2002 October 12-13, Rome, Italy.

Stepp JR, Moerman DE (2001) The importance of weeds in ethno-pharmacology. J Ethnopharmacol 75: 19-23.

Tageo (2010) People's Republic of Bangladesh. http://www.tageo.com/index-e-bg-v-85d-m3857931.htm Accessed 5 February 2010.

Trotter RT, Logan MH (1986) Informant consensus: A new approach for identifying potentially effective medicinal plants. Pages 91-112 in Plants in indigenous medicine and diet, behavioural approaches. Redgrave Publishing Company, Bredford Hills, New York.

Uddin MZ (2001) Exploration, documentation and germplasm collection of plant genetic resources of Rema-Kalenga Wildlife Sanctuary (Habiganj) in Bangladesh. Ph.D. Thesis. Department of Botany, Dhaka University.

Uddin MS, Chowdhury MSH, Khan MMMH, Uddin MB, Ahmed R, Baten MA (2006) In vitro propagation of Stevia rebaudiana Bert in Bangladesh. Afr J Biotech 5: 1238-1240.

Uniyal RC, Uniyal MR, Jain P (2000) Cultivation of medicinal plants in India. TRAFFIC India and WWF, New Delhi, India.

Yineger H, Yewhalaw D (2007) Traditional medicinal plant knowledge and use by local healers in Sekoru District, Jimma Zone, Southwestern Ethiopia. J Ethnobiol Ethnomed 3: 1-24. 
Yineger H, Kelbessa E, Bekele T, Lulekal E (2008) Plants used in traditional management of human ailments as Bale Mountains National Park, Southeastern Ethiopia. J Med Plant Res 2: 132-153. 
Appendix A. Medicinal plants and their relative importance recorded in the study areas

\begin{tabular}{|c|c|c|c|c|c|}
\hline \multicolumn{2}{|l|}{ Species } & \multirow[t]{2}{*}{ Habit } & \multirow[t]{2}{*}{ Family } & \multirow[t]{2}{*}{ Parts used } & \multirow[t]{2}{*}{ Ailments } \\
\hline Botanical Name & $\begin{array}{l}\text { Local } \\
\text { Name }\end{array}$ & & & & \\
\hline $\begin{array}{l}\text { Abelmoschus } \\
\text { moschatus Medik. }\end{array}$ & $\begin{array}{l}\text { Bon } \\
\text { Derosh }\end{array}$ & Shrub & Malvaceae & Root & Leg swelling \\
\hline $\begin{array}{l}\text { Adhatoda vasica } \\
\text { Nees. }\end{array}$ & Basak & Shrub & Acanthaceae & Leaf & Asthma, Cough, Fever, Cold \\
\hline $\begin{array}{l}\text { Aegle marmelos } \\
\text { (L.) Correa. }\end{array}$ & Bel & Tree & Rutaceae & Fruit & $\begin{array}{l}\text { Heat stroke, ulcer, gastri } \\
\text { indigestion, constipation }\end{array}$ \\
\hline Allium ceipa L. & Piaj & Herb & Liliaceae & Tuber, leaf & Snake bite, Cold, \\
\hline Allium sativum L. & Roshun & Herb & Liliaceae & Bulb & $\begin{array}{l}\text { Head ache, Stomach trouble } \\
\text { heart disease, trouble in urinati }\end{array}$ \\
\hline $\begin{array}{l}\text { Alocasia indica } \\
\text { Schott. }\end{array}$ & Harinpaya & Herb & Araceae & Whole plant & Gastric pain, Stomach trouble \\
\hline Alocasia spp & Kochu & Herb & Araceae & $\begin{array}{l}\text { Petiole, } \\
\text { flower }\end{array}$ & Leeche bite, cuts \& wounds \\
\hline Aloe indica Tow. & $\begin{array}{l}\text { Grito- } \\
\text { kumari }\end{array}$ & Herb & Liliaceae & Leaf & Ulcer, constipation, skin dullne \\
\hline $\begin{array}{l}\text { Alstonia scholaris } \\
\text { Br. }\end{array}$ & Chatim & Tree & Apocynaceae & Bark & Diabetes \\
\hline $\begin{array}{l}\text { Annas comosus } \\
\text { (L.) Merr. }\end{array}$ & Anarosh & Shrub & Bromeliaceae & $\begin{array}{l}\text { Tender leaf, } \\
\text { ripe fruit }\end{array}$ & Intestinal worm, fever \\
\hline Areca catechu L. & Shuari & Palm & Arecaceae & Seed & Flatulence, vomiting \\
\hline $\begin{array}{l}\text { Artocarpus } \\
\text { heterophyllus } \\
\text { Lmak. }\end{array}$ & Kanthal & Tree & Moraceae & Inflorescence & Apathy to food \\
\hline $\begin{array}{l}\text { Artocarpus } \\
\text { lakoocha Roxb. }\end{array}$ & Dewa & Tree & Moraceae & Tender leaf & Asthma \\
\hline $\begin{array}{l}\text { Asparagus } \\
\text { racemosus Willd. }\end{array}$ & Shotomuli & $\begin{array}{l}\text { Creepe } \\
\mathrm{r}\end{array}$ & Asparagaceae & Root & Low content of sperm in male \\
\hline $\begin{array}{l}\text { Azadirachta indica } \\
\text { Juss. }\end{array}$ & Neem & Tree & Meliaceae & Leaf & $\begin{array}{l}\text { Scabies, Skin disease, cuts \& } \\
\text { diabetes }\end{array}$ \\
\hline $\begin{array}{l}\text { Bambusa vulgaris } \\
\text { Schred. }\end{array}$ & $\begin{array}{l}\text { Barak } \\
\text { Bansh } \\
\end{array}$ & Tree & Graminae & Bark dust & Cut \\
\hline $\begin{array}{l}\text { Cajanus cajan (L.) } \\
\text { Millsp. }\end{array}$ & Orhor & Shrub & Fabaceae & Leaf & Jaundice, Apathy to food intak \\
\hline Calotropis & Aphon & Shrub & $\begin{array}{l}\text { Asclepiadacea } \\
\text { e }\end{array}$ & Leaf & Joint ache, rheumatism \\
\hline
\end{tabular}




\begin{tabular}{|c|c|c|c|c|c|}
\hline gigantean $\mathrm{L}$. & & & & & \\
\hline $\begin{array}{l}\text { Cassia angustifolia } \\
\text { Vahl. }\end{array}$ & $\begin{array}{l}\text { Sonamukh } \\
\text { i }\end{array}$ & Shrub & Fabaceae & Leaf & Gastric pain \\
\hline Cassia fistula $\mathrm{L}$. & Sonalu & Tree & Fabaceae & Tender leaf & Intestinal worm \\
\hline Cassia alata L. & Daad & Shrub & Fabaceae & Leaf & Scabies, skin disease \\
\hline $\begin{array}{l}\text { Centella asiatica } \\
\text { (L.) Urban. }\end{array}$ & Thankuni & Herb & Umbelliferae & Whole plant & $\begin{array}{l}\text { Stomach trouble, } \\
\text { Stammering, Cold, cough }\end{array}$ \\
\hline $\begin{array}{ll}\begin{array}{l}\text { litrullus } \\
\text { colocynthis }\end{array} \\
\text { Schrad. }\end{array}$ & Makal & $\begin{array}{l}\text { Creepe } \\
\text { r }\end{array}$ & Cucurbitaceae & Fruit & Birth control \\
\hline Citrus spp. & Komla & Tree & Rutaceae & Fruit skin & Stomach pain \\
\hline $\begin{array}{l}\text { Citrus aurantifolia } \\
\text { (Chris. \& } \begin{array}{l}\text { Pan.) } \\
\text { Sw. }\end{array}\end{array}$ & Lemu & Shrub & Rutaceae & Leaf & Pyorrhea \\
\hline $\begin{array}{l}\text { Clerodendrum } \\
\text { viscosum Vent. }\end{array}$ & Bhat & Shrub & Verbenaceae & Leaf, root & $\begin{array}{l}\text { Fever, Gastric pain, Cough, D } \\
\text { earache }\end{array}$ \\
\hline $\begin{array}{l}\text { Coccinea } \\
\text { cordifolia L. }\end{array}$ & Telakucha & $\begin{array}{l}\text { Creepe } \\
\text { r }\end{array}$ & Cucurbitaceae & Leaf & Diabetes \\
\hline Cocos nucifera $\mathrm{L}$. & Narkel & Palm & Arecaceae & $\begin{array}{l}\text { Fresh juice, } \\
\text { fruit }\end{array}$ & $\begin{array}{l}\text { Burning in urination, heat } \\
\text { diarrhea, dysentery }\end{array}$ \\
\hline Curcuma longa $\mathrm{L}$. & Holud & Herb & Zingiberaceae & Rhizome & Skin dullness, wounds in livest \\
\hline $\begin{array}{l}\text { Cynodon dactylon } \\
\text { Pers. }\end{array}$ & Durba & Herb & Graminae & Tender leaf & Cut and wounds \\
\hline Datura metel L. & Dhutura & Shrub & Solanaceae & Leaf & Scabies \\
\hline $\begin{array}{l}\text { Dillenia pentagyna } \\
\text { Roxb. }\end{array}$ & Hargeza & Tree & Dilleniaceae & Bark & Cut, Mosquito bite \\
\hline $\begin{array}{l}\text { Elaeocarpus } \\
\text { robustus Roxb. }\end{array}$ & Jolpai & Tree & $\begin{array}{l}\text { Elaeocarpacea } \\
\mathrm{e}\end{array}$ & Fruit & Apathy to food \\
\hline $\begin{array}{l}\text { Emblica officinale } \\
\text { L. }\end{array}$ & Amloki & Tree & Euphorbiaceae & Fruit & $\begin{array}{l}\text { Jaundice, Asthma, Dysentery, } \\
\text { Stomach trouble, Apathy } \\
\text { intake, Fever, Weakness, } \\
\text { gastric pain, ulcer }\end{array}$ \\
\hline $\begin{array}{l}\text { Ferula asafoitida } \\
\text { L. }\end{array}$ & $\begin{array}{l}\text { Heez } \\
\text { Gaach }\end{array}$ & Shrub & Apiaceae & Slender stem & Asthma, Cough \\
\hline Ficus hispida L. & Dumur & Tree & Moraceae & Inflorescence & Diabetes \\
\hline $\begin{array}{lr}\text { Hibiscus } & \text { rosa- } \\
\text { sinensis L. } & \\
\end{array}$ & Joba & Shrub & Malvacea & Flower & $\begin{array}{l}\text { Sexual weakness in male, } d \\
\text { skin problem in hand palm }\end{array}$ \\
\hline Jatropha curcas L. & Jamalgota & Shrub & Euphorbiaceae & Latex & Scabies, Skin disease \\
\hline $\begin{array}{l}\text { Kalanchoe pinnata } \\
\text { (Lamk.) Pers. }\end{array}$ & $\begin{array}{l}\text { Pathor } \\
\text { kuchi }\end{array}$ & Herb & Crassulaceae & Leaf & Cough in babies \\
\hline $\begin{array}{l}\text { Lawsonia inermis } \\
\text { L. }\end{array}$ & Mendi & Shrub & Lythraceae & Leaf & Burning in urination, dandruff, \\
\hline $\begin{array}{l}\text { Leucus aspera } \\
\text { Willd. }\end{array}$ & $\begin{array}{l}\text { Dondo } \\
\text { Kolosh }\end{array}$ & Herb & Lamiaceae & Leaf & Cough \\
\hline polyantha & Menda & Tree & Lauraceae & Leaf & Diarrhoea, Dysentery \\
\hline
\end{tabular}




\begin{tabular}{|c|c|c|c|c|c|}
\hline Juss. & & & & & \\
\hline $\begin{array}{l}\text { Mangifera indica } \\
\text { L. }\end{array}$ & Aam & Tree & Anacardiaceae & Tender leaf & Asthma, teeth disease \\
\hline $\begin{array}{l}\text { Mikania scandens } \\
\text { (L.) Willd. }\end{array}$ & $\begin{array}{l}\text { Uzari/Ref } \\
\text { ugee lota }\end{array}$ & $\begin{array}{l}\text { Creepe } \\
\text { r }\end{array}$ & Compositae & Leaf & Cut, Jaundice, dysentery, diabe \\
\hline $\begin{array}{l}\text { Momordica } \\
\text { charantea L. }\end{array}$ & Korola & $\begin{array}{l}\text { Creepe } \\
\mathrm{r}\end{array}$ & Cucurbitaceae & Leaf, fruit & Diabetes \\
\hline Musa spp. & Kela & Shrub & Musaceae & Green fruit & Dysentery \\
\hline $\begin{array}{l}\text { Ocimum sanctum } \\
\text { L. }\end{array}$ & Tulshi & Shrub & Lamiaceae & Leaf & Leg swelling, Fever, Cough, C \\
\hline $\begin{array}{l}\text { Paederia foetida } \\
\text { L. }\end{array}$ & Padra Pata & shrub & Rubiaceae & Leaf & Diarrhoea, Dysentery \\
\hline Piper betel L. & Paan & $\begin{array}{l}\text { Creepe } \\
\text { r }\end{array}$ & Piperaceae & Leaf & $\begin{array}{l}\text { Flatulence, indigestion, cong } \\
\text { muscles, cuts \& wounds }\end{array}$ \\
\hline Piper longum L. & $\begin{array}{l}\text { Pipul } \\
\text { Morich }\end{array}$ & $\begin{array}{l}\text { Creepe } \\
\mathrm{r} \\
\text { (vine) }\end{array}$ & Piperaceae & Fruit & Cough, Asthma \\
\hline Piper nigrum L. & $\begin{array}{l}\text { Gol } \\
\text { Morich }\end{array}$ & $\begin{array}{l}\text { Creepe } \\
\mathrm{r} \\
\text { (vine) }\end{array}$ & Piperaceae & Seed & Cough, Asthma \\
\hline $\begin{array}{l}\text { Plantago ovata } \\
\text { Forst. }\end{array}$ & Isopgul & Herb & Compositae & Seed coat & Heat stroke, gastric pain, const \\
\hline $\begin{array}{l}\text { Punica granatum } \\
\text { L. }\end{array}$ & Dalim & Tree & Puniaceae & Leaf & Intestinal worms \\
\hline $\begin{array}{l}\text { Solanum indicum } \\
\text { L. }\end{array}$ & $\begin{array}{l}\text { Bon } \\
\text { Begun }\end{array}$ & Shrub & Solanaceae & Fruit & Flatulence \\
\hline $\begin{array}{ll}\text { Sterculia } & \text { villosa } \\
\text { Roxb. } & \\
\end{array}$ & Udal & Tree & Sterculiaceae & $\begin{array}{ll}\text { Tender } & \text { leaf } \\
\& \text { twig } & \end{array}$ & $\begin{array}{l}\text { Gastric pain, } \quad \text { Stomach } \\
\text { Premature ejaculation in male }\end{array}$ \\
\hline $\begin{array}{l}\text { Swertia chirata } \\
\text { Ham. }\end{array}$ & Chirota & Herb & Sapindaceae & Whole plant & $\begin{array}{l}\text { Chronic fever, gastric pain, } \\
\text { liver disease }\end{array}$ \\
\hline $\begin{array}{l}\text { Syzygium cumini } \\
\text { (L.) Skeels. }\end{array}$ & Jam & Tree & Myrtaceae & Seed & Diabetes \\
\hline Tagetes erecta L. & Genda & Herb & Compositae & Tender leaf & Cut \& wounds \\
\hline $\begin{array}{l}\text { Tamarindus indica } \\
\text { (L.) Cogn. }\end{array}$ & Tentul & Tree & Fabaceae & $\begin{array}{l}\text { Tender leaf, } \\
\text { Fruit }\end{array}$ & $\begin{array}{l}\text { Burning in urination, Rhel } \\
\text { Female disease, diabetes }\end{array}$ \\
\hline $\begin{array}{l}\text { Terminalia arjuna } \\
\text { Bedd. }\end{array}$ & Arjun & Tree & Combretaceae & $\begin{array}{l}\text { Tender leaf, } \\
\text { Bark }\end{array}$ & $\begin{array}{l}\text { Heart disease, Apathy to foor } \\
\text { Weakness }\end{array}$ \\
\hline $\begin{array}{l}\text { Terminalia } \\
\text { belerica Roxb. }\end{array}$ & Bohera & Tree & Combretaceae & Fruit & $\begin{array}{l}\text { Fever, Apathy to food } \\
\text { Weakness, Malaria, Jaundice, } \\
\text { Asthma, Gastric pain, ulcer }\end{array}$ \\
\hline $\begin{array}{l}\text { Terminalia } \\
\text { chebula Retz. }\end{array}$ & Hortoki & Tree & Combretaceae & Fruit & $\begin{array}{l}\text { Fever, Apathy to food intake, } \\
\text { trouble, Asthma, Weakness, } \\
\text { gastric pain, ulcer }\end{array}$ \\
\hline $\begin{array}{l}\text { Trewia nudiflora } \\
\text { L. }\end{array}$ & $\begin{array}{l}\text { Chagol } \\
\text { Ledi/ } \\
\text { Motkila }\end{array}$ & Tree & Euphorbiaceae & Leaf & $\begin{array}{l}\text { Chronic fever, Stomach } \\
\text { Jaundice }\end{array}$ \\
\hline
\end{tabular}




\begin{tabular}{|l|l|l|l|l|l|}
\hline $\begin{array}{l}\text { Trigonella foenum- } \\
\text { graceum L. }\end{array}$ & Methi & Shrub & Fabaceae & Seed & Diabetes \\
\hline Vitex negundo L. & Ninda & Shrub & Verbenaceae & Leaf, branch & Toothache, tonsil pain \\
\hline $\begin{array}{l}\text { Zingiber officinale } \\
\text { Rosc. }\end{array}$ & Ada & Herb & Zingiberaceae & Tuber & Cough, cold, Flatulence \\
\hline $\begin{array}{l}\text { Zingiber zerumbet } \\
\text { Smith. }\end{array}$ & Ekangi & Herb & Zingiberaceae & Tuber & Gastric pain \\
\hline
\end{tabular}

$\mathrm{F}=$ Forested region, $\mathrm{NF}=$ Non-forested region, $\mathrm{B}=\mathrm{Both}$ forested and non-forested region

* the values in parentheses in 5th column indicate the RI of species in non-forested region 